\title{
Co-Creation of the Tourist Experience via Internet: Towards Exploring a New Practice
}

\author{
Mohamed Berrada \\ PhD Student, University Hassan 1st, Settat, Morocco and Unversity Lumière Lyon 2, Lyon, France
}

\begin{abstract}
2017 Research Leap/Inovatus Services Ltd. All rights reserved.

DOI: $10.18775 /$ jibrm.1849-8558.2015.25.3003 URL: http://dx.doi.org/10.18775/jibrm.1849. $\underline{8558.2015 .25 .3003}$

\section{Keywords:}

Value Co-Creation, Tourism, Tourist Experience, Internet, Satisfaction

The purpose of this article is to explore the potential value added to the concept of value cocreation applied to the tourism sector and to investigate how tourists can conceive their participation through the Internet in the design of their trip with tourist producers. To do so, a survey was conducted on tourists in Morocco who have never used this practice which still does not exist locally. The objective behind this choice is to explore whether this new approach will raise the interest of the tourists and be accepted as an innovative way to live differently the tourist experience. The results of the descriptive analysis showed that Moroccan tourists by using the Internet - think they can create value by being involved in the process which makes them satisfied. It would be stimulating as a future research to test tourists' satisfaction after living an experience they really co-created. After all, co-creation is still a new concept in tourism that will be developed through further research and become a real trend. Especially tourists are currently looking for meaning, support, interaction, involvement, participation, authenticity, personalization of offers and unique experience. This article opens up new paths of research and allows tourist producers to know the future trends in this sector.
\end{abstract}

\begin{abstract}
1. Introduction
Nowadays, tourism market has known rapid change since the advent of web technologies and the emergence of online travel agencies. The number of intermediaries between tourists and tourist producers has even reduced. The various destinations and the different tourist producers have to face new competitors on line, the lack of financial resources, the progress of Internet technology, the divergence in actors' interests, the competition between destinations and the ever changing expectations of tourists (Binkhorst, 2006). These factors push tourist producers to ask several important questions such as how and why tourists travel, how to create value for the tourist and produce a memorable experience during a tourist journey, how this value can be consumed before, during and after a trip.
\end{abstract}

In such a competitive environment, companies are in continuous need to distinguish themselves in order to differentiate from others and remain competitive in a market which is increasingly competitive. Times have changed pushing tourism companies to rethink their development strategies to ensure their sustainability. In recent years, interest has focused on innovation which seems to be an effective way to stand out from competition especially in a market where business strategies have become easily reproduced. Companies have then realized that being the first to develop an idea or develop a new concept on the market is essential to get noticed and attract attention. As a matter of fact, tourist producers are constantly seeking different ways to succeed the tourist experience and reach tourists' satisfaction, which will provide the destination with a differentiated image, enhance its brand equity and consolidate its advantageous position (Prebensen et al., 2014). To do so, tourism providers must innovate more to better respond to the tourist of the $21 \mathrm{st}$ century (Tan et al., 2014). Therefore, innovation is seen as a major axis to remain competitive, and anticipate future trends and needs by using optimally new technologies.

However, tourism businesses can no longer rely solely on their internal resources to innovate and create value. Thus, they have directed their strategies towards more openness by integrating tourists in the value creation process. This integration is actually materialized by the customers' participation and cooperation with tourism companies to develop personalized experiences that meet their needs and expectations. Therefore, the concept of co-creation of experience is interesting in the tourism sector as it adds value to all stakeholders and contributes to the uniqueness and authenticity of the destination (Binkhorst, 2006). Moreover, the current tourist context forces companies in the tourism sector to integrate this new approach to their innovation policy in order to understand the intangible aspect of tourism, the process of creating unique experiences, the realization of dreams and the achievement of tourists fantasies (Lichrou et al., 2008).

Consequently, due to the Internet, people are in the process of (re) gain power, to regain control over their lives, and organize themselves, with each other, into networks (Scherer, 2012). Currently, creation, contribution and to sharing by the means of the Internet has become the watchwords of this era characterized by the dominance of digital. Pine and Gilmore (1999) highlight the significant contribution that brings the new technologies of the Internet such as Web 2.0, social networking and mobile Internet in the value co-creation and the experience's achievement. With these new tools, customers are no longer subject of the producers, but they take part in defining the interaction and context by providing personal touch to the tourism product (Prahalad \& Ramaswamy, 2003). In fact, the emergence and development of the Internet as a research tool 
and information sharing have greatly facilitated the task of tourists who now start to study, compare, evaluate and select the most appropriate destination for their needs and expectations. Then, tourists seek a memorable experience (Pine \& Gilmore, 1999) and for this, they shape their own tourism products in participating in the value co-creation with tourist destinations producers (Oh et al., 2007). These facts force producers to develop innovative value propositions offering unique activities and personalized experiences in creative spaces (Prahalad \& Ramaswamy, 2004; Gross and Brown, 2006), especially that providing standardized services is paradoxical with a sector like tourism where the experience is intensive (Dekhili \& Hallem, 2016).

The co-creation concept in tourism is not sufficiently developed in the literature and researchers in this exciting field continue to place the tourist at the end of the chain by limiting him to a reactive role vis-à-vis to the tourist experience designed and delivered by one or many providers $(\mathrm{Li}$ \& Petrick, 2008; Binkhorst \& Den Dekker, 2009; Kreziak \& Frochot, 2011). However, the new postmodern tourist is increasingly looking for new and enriching experiences and aspires to much more than being served passively by the tourism industry (Tan et al., 2014). Tourists have become now more demanding and much more active and want to be involved in their trip design, as well as in the creating process of the tourist experience. Consequently, authors such as Campos et al. (2015) report "an increasing demand for more participative and interactive experiences" (p.1), especially in tourism industry which is more concerned with making and selling experiences (Ihamäki, 2012; Kim, 2010). As a matter of fact, "experience is the cornerstone of tourism, its alpha and omega" (Zàtori, 2013:12), and in turn, tourism is the primary sector of experience creation (Ibid.) and the biggest experience generator (Binkhorst, 2006). Besides, the recent extant literature on tourism experiences starts to stress the role of the tourist as co-creator of the experience (Campos et al., 2015; Prebensen et al., 2013a; Tan et al., 2013).

Otherwise, tourism professionals worldwide do not all have a perfect awareness and understanding of the concept, others haven't formed yet a concrete idea nor on the usefulness of this new practice nor on its effectiveness. However, research is still ongoing to deepen and clarify the concept. Notwithstanding those tourism strategies differ and evolve, these actors and tourism companies have only one goal, that is, to achieve customer satisfaction. In fact, before investing in this new approach and practice, it makes sense for any company in the tourism sector to be able to study the possible and eventual satisfaction with this new concept among tourists who have never used this innovative strategy. It is done with the purpose to measure their interest and to collect their opinions. The research question to which we will attempt to answer in this article is: "Will tourists be satisfied with their tourism experience if they are involved in co-creating their travel via the Internet?"

Our paper is organized into five parts. First of all, introduction in which we define the research context and problem. Then, a theoretical framework that includes the definition of the key concept of our article, that is co-creation, its linking, and usefulness to tourism. The role of the Internet which is placed in the process will be highlighted after. We will also present the point of divergence in the literature following our analysis. The methodology will later be described in order to be reproducible. We will also present briefly the main results of our analysis. The last section will discuss these results and conclude the paper by suggesting future research directions.

\section{Theoretical Framework}

The co-creation of value is a recent concept that has attracted the attention of many researchers in several fields and professionals in many industries such as tourism sector where the co-creation of the trip or the tourist experience is an upcoming trend. The researchers focused on this new concept and tried to study each aspect of the process by finding factors that affect value creation, understanding reasons and motivations that push customers to participate in the co-creation process and exploring how they do it, studying their perceptions and collecting their thoughts about their collaboration with the producer and their involvement in the value generating process. Also, the outcomes and aftereffects of the process are still unknown and undefined. As a result, the study of consumer co-creative behavior in the tourism context is now considered as a major priority in marketing research (Dekhili and Hallem, 2016; Grisseman and Stokburger-Sauer, 2012; Shaw et al., 2011) as empirical studies have paid very little attention to the impact of co-creation on consumers themselves (Guo et al., 2013). Hence it is the utility of our research

\subsection{Co-Creation Concept in Tourism}

Based on the definition of Prahalad and Ramaswamy (2004), co-creation is a management initiative, or a form of economic or business strategy focusing specially on customer experience and interactive relationships as it brings different parties together, such as a company and a group of customers, in order to jointly produce a mutually valued outcome and create at the end a value rich experience. In other words, it is a business strategy based on consumers' past experiences and interactive relationships. It allows and encourages a more active participation of the customer to create a richer experience value. Personalization and user participation are next central elements of the experience (Boswijk et al., 2007). The emergence of the logic of value co-creation implies taking into account the expertise and customer knowledge, which are or may be a source of value and competitiveness of the business (Prahalad and Ramaswamy, 2000; Vargo and Lusch, 2004; Von Hippel, 2005). In fact, the involvement of customers in the co-creation process is an important strategy for companies competing to meet the personalized demands and obtain competitive advantages (Prahalad and Ramaswamy, 2000, 2003). Through the co-creation of value, companies aim to develop products and services tailored to the market and to link interactive and engaging relationship with its customers. Companies seek also the achievement of objectives in terms of innovation, customer participation in the value production process and his collaboration with the company. It will ensure the personalization of its offer and its adaptation to the needs and expectations of customers.

In the logic of co-creation of tourism value, tourism companies must consider tourists as participants in the creation of the product and the tourist experience and not as mere spectators (Jager, 2009). According to Prahalad and Ramaswamy (2003), customers play a key role in the definition of co-created value and the experience's environment. Thus, co-created value is linked to the individual experience resulting from his interaction with the company (Holbrook, 1999). Indeed, the tourist experience occurs when tourist consumption and production meet (Andersson, 2007). Therefore, experiences designed for and by tourists are social constructions stemming from a continuous process of learning and creative collaboration between the various tourism stakeholders. They are based on the relational without omitting the important place of emotion in tourism because as Lashley (2008) defines it, tourist experience is emotionally engaging which leads to memorability. In fact, experiences are memorable (Pine and Gilmore, 1999) and must be an extraordinary, unforgettable and memorable moment lived by the 
consumer during his meeting with his supplier (Bouchet, 2004) Likewise, experiences are both individual and customized as they act on different levels, emotionally, physically, intellectually or even spiritually (Carù and Cova, 2002). Also, they are highly personal, subjectively perceived, intangible, always fleeting and continuously on-going (Zlátori, 2013). The tourist experience has then a personal character (Larsen, 2007). Therefore, experience in tourism can be either considered as a true story, personal and unique or designed and transformed into the community. At last, Walls et al. (2011) define tourist experience as "a multidimensional construct comprised of a number of external and internal factors that shape and influence consumer experiences, which can exist only if the participating consumer is willing and able to participate" (p.19).

Accordingly, the co-creation of the tourist experience has its full extent because it can be transmitted by tourists and shared in their community. On the one hand, tourism companies are now able to provide compelling and memorable experiences to tourists due to their involvement and contribution to the process. It represents a strong competitive advantage to distinguish the company in a competitive market but also the difference that makes the tourists choose a specific tourism company. On the other hand, the co-creation allows tourists to do things rather than just undergo the experience designed by tourism producers and also engage themselves in activities for self-development, explore multisensory environments, and connect to other people as they are directly involved in creating and choreographing their activities from moment to moment (Campos et al., 2015).

\subsection{Co-Creation in Tourism via the Internet}

Today, due to the emergence of Internet, exchange platforms (as social networks) and 2.0 technologies, customers become active, they are informed and they exchange information on products and services as well as all the interactions they have with the company (Prahalad and Ramaswamy, 2004). Therefore, companies can no longer launch on the market products or services without taking advantage of customer experiences that represent the sum of the interactions the customer has with the company throughout the whole life of product or service and involve these experiences upstream throughout the design process. Thus, the value co-creation with customers is a dynamic, creative and socialbased collaboration between companies and customers who are totally committed and take part in the development of new products and services.

Nowadays, the Internet offers the opportunity for companies to develop closer relationships with customers. Buhalis and Licata (2002) have demonstrated this strong connection between both actors by conducting a survey in which some interviewees mentioned that "actually the Internet is offering a better service and experience for the consumer as their interaction with tourism organizations can be more meaningful" (p.211). Moreover, the interviewees added that "instead of meeting an inexperienced travel consultant in the high street shop, after having struggled to park and waited in the queue for their turn, a number of travel companies already offer specialised support through their calling centres and enable consumers to ask specific questions to a product/property/destination specialist" (Ibid.). Thus, Binkhorst (2006) considers that Internet, IDTV and mobile communication devices are the three most significant online platforms for the near future. He argues also that these technological developments will make meaningful dialogues possible with each tourist and will provide an experiential environment where innovations in tourism can be based on the co-creation experience.
Accordingly, information systems including the Internet will help us to understand the three major phases that make the overall experience of the tourist which are: planning, tourism and the memory (Watson et al., 2004). Thereby, the interaction and the close collaboration between tourists and tourist producers will secure the delivery of unique value to tourists so as they will never have the same tourist experience (Cova et al., 2011). It is because they will take advantage of past experiences to improve future ones, use the Internet to search information and have a direct contact with the various on-site service providers in order to customize their travel experience and live it fully. Tourists will feel so independent and responsible for the production of the experience they want to live, and co-creators of value they will get from the tourism producers offerings (Prahalad and Ramaswamy, 2004). We will explain in the next two paragraphs how the Internet can be used to co-create value during the three stages of the tourist experience.

During the planning, the tourist can collect new information about the destination or a specific tourism activity from the web which increases and diversifies sources of information. Indeed, thanks to this tool, the tourists are connected with the rest of the world and they are currently facing a glut of information to plan their travel activities (Watson et al., 2004). During tourism's step, tourists need information in real time on the destinations, its tourist attractions and the available services and leisure. For instance, they can search and receive travel information on their mobile devices, so they will be able to modify the planned activities or to co-design new ones taking into account tourism producer's advice and recommendations. At the last step relative to the memory, tourists share their opinion on the destination, exchange and describe their stories and experiences to others (potential visitors, other tourists but also family members, colleagues, friends, and so on) and may even recommend or not the destination.

Therefore, in the logic of co-creation, tourism companies will seek knowledge and past experiences of visitors in order to co-create value to tourists. Thus, during the planning phase, tourism companies and customers work together upstream to co-design idea and trip or to codevelop the tourism activity (Payne et al. 2008). Tourists do not want more preconceived travel but they want instead to participate closely with suppliers in the definition of their journey, and it goes through the opening of a dialogue and sharing of knowledge between the two actors (provider and tourist) (Prahalad and Ramaswamy, 2004). During the second phase associated with travel, the tourist co-creates activities, services and leisure linked to tourism with local service providers to ultimately enjoy unique and memorable experiences. The tourist will use the Internet to access information in order to modify the service. He can also produce part or the entire tourist offer. Through the Internet, tourists co-create their most authentic tourism experiences. The final step relates to the extension of the tourist experience and shares it with potential visitors through new information and communication technologies, including the Internet, which proves to be an effective tool for promoting the destination. In fact, the tourists' opinions on the Internet can have a significant impact, positive or negative, on the reputation of destinations and tourism companies. Afterward, the co-creation with tourism producers will turn into a co-creation of 'Consumer to Consumer' (C2C) tourism experiences (Binkhorst, 2006; Huang and Hsu, 2010; Rihova et al., 2014).

The conceptual analysis showed that the tourists' active involvement in the co-creation process is an important strategy for tourism businesses competing to meet the personalized demands of customers by delivering a unique value and offers a new experience. Otherwise, we found a contrast in the literature among researchers about satisfaction. On one 
hand, some authors have agreed that consumers or tourists' involvement in the process of co-creating their trip generate and increase their satisfaction, so they can remember the whole tourist experience (Shaw et al., 2011). Thus, the tourists' involvement in producing memorable experiences is seen both as a key element to achieve tourist satisfaction and as critical to the destination sustainability and competitiveness (Ritchie and Crouch, 2003). In addition, Lee (2012) and Grissemann and Stokurger-Sauer (2012) demonstrate in their research that the degree of tourists' involvement influences their satisfaction and has also a strong impact and direct effect on their willingness to participate as well as the outcome of the co-creation process. Prebensen and al. (2013b) state as well that the more a customer puts time and effort into an experience, the more he will sense a positive added value, and then, will be satisfied. In the other hand, Vargo and Lusch (2006) believe that "there is no satisfaction until an offering is used, experience and perception are essential to value determination" (p.44). Accordingly, despite the level of tourists' involvement in the co-creation process, they can't be satisfied until they try out and live the entire tourist experience and sense the added value. Indeed, tourists value the whole tourist experience at the end of the trip after they have contributed to the co-creation process and they have lived the experience (Vargo and Lusch, 2006).

In order to answer our research question: "Will tourists be satisfied with their tourism experience if they are involved in co-creating their travel via the Internet?" and to be able to position itself among one of the two opposing groups of authors, we conducted a survey among Moroccan tourists who have never used this practice before to define and organize their trip. The purpose behind this target's choice is to assess the potential success of this new approach as well as to provide a basis for tourism professionals to develop innovative strategies based on the co-creation concept.

\section{Methodology}

The approach used to address our research problem is a concept test to explore the idea of this new practice of the trip co-creation via Internet and to test the potential of its acceptance by tourists. The main advantage of this test is to assess the interest of tourists and especially understand the reasons for this interest or disinterest. If the concept really interests clients, tourism producers like travel agencies will be motivated to integrate and invest in this strategy.

This study aims to know if tourists think their involvement in the process will lead to their satisfaction with this new practice that will change their trip design and will offer a new way to live the tourist experience. Our choice is focused on the Moroccan context because the co-creation practice in tourism has still not emerged in this country. Thus, it would be interesting to collect tourists' opinions as well as their willingness to take part in this new tourist experience co-creation process. We will measure also their satisfaction degree regarding their eventual participation in this new concept.

In a practical way, the field research is conducted in the form of the online questionnaire using the social network Facebook to help us identify and target groups containing Moroccan tourists. Three public groups in Facebook were selected namely: Moroccan Ministry of Tourism, Tourism Observatory and National Confederation of Tourism. We considered Facebook as a quick and effective way to reach a significant number of respondents of all ages and from all socio-professional categories. Indeed, we have succeeded to attain 317 replies in five days from 01/17/2016 to $01 / 21 / 2016$. In addition, Facebook has enabled us to assist respondents in the questionnaire but especially to present and explain the co-creation concept, and how this approach can be used to create value and ultimately produce a memorable tourist experience. Internet was then introduced as an effective technological tool while detailing its usefulness and its role in the process, which generated an excitement and interest among respondents who wanted to discover this new practice.

Due to the interactive dimension of the research topic, the questionnaire contains different types of questions to arouse the respondents' curiosity and interest. The administered questionnaire consists of four sections. The questions of the first section were chosen so as to enable us to define the behavior and different habits of tourists when choosing a trip and its planning. The second part concerns the heart of the topic which is the cocreation in tourism. The goal is to know the respondents' opinions on the concept and measure their willingness to participate. The third section is about the co-creation process in tourism via the Internet, where questions were designed to find out why tourists use the Internet, the interest in such approach via Internet and willingness to use it, their perception of the value co-created, and how they imagine their contribution to the process of the tourist producer using Internet during the three phases of a trip. The Likert scale was used to measure the tourists' satisfaction level of the tourist experience co-created. The last section serves to regroup the respondents' personal information.

\section{Results}

A descriptive analysis of data allows to highlight the following important results:

\section{Profile of respondents:}

Our sample consisted of 55\% women and $45 \%$ men, all age groups were represented with a predominance of slice 18-25 with 50\% and 26-35 with $32 \%, 73 \%$ of them were single. Most of the tourists travel 2 to 3 times per year or even more than 3 times. The majority chooses his destinations following the recommendations of family, relatives, friends or colleagues but there is also a significant part that uses the Internet or chooses randomly. However, $10 \%$ of respondents resort to travel agencies.

Most respondents (75\%) choose to personally plan the trip and therefore, prefer customized travels and experiences, while only $14 \%$ opt for trips organized by travel agencies.

\section{Concept test:}

93\% ignore the concept of co-creation in tourism but $72 \%$ want to be involved in their trip generating process and the majority (85\%) of them (tourists who want to be involved) affirm the desire to be highly involved. Indeed, they perceive the opportunity to collaborate with tourism producers as interesting (54\%) and rather interesting (43\%).

Most respondents (90\%) never had the opportunity to be involved in the design of their travel and 54\% think they will create value if they participate in the process and they also declare they will be very satisfied $(27 \%)$ and rather satisfied (38\%) of the tourism experience that will be co-created.

\section{Co-creation of tourism experience through the Internet:}

Tourists who want to be involved in the process use Internet for many reasons, but especially to search information about destinations (90\%), to plan and organize the trip (59\%). Besides, $85 \%$ of them want to use the Internet to collaborate with the tourism producer and $69 \%$ affirm they will co-create value and judge their contribution as very useful (39\%) and useful $(58 \%)$. 
Finally, tourists who think that they will create value during the cocreation of their tourist experience by using the Internet will be very satisfied $(27 \%)$ and rather satisfied $(46 \%)$ of the tourist experience that will be co-created. Nevertheless, we don't have to neglect that $25 \%$ of them do not know until they live the whole experience as they have justified in their answers

\section{Discussion and Conclusion}

The objective of this work was to show if the tourist (by using the Internet) is satisfied once he is involved in the trip co-creation process before he even lives the experience. In fact, the literature has shown that once the tourist takes part in the process of co-creation of his journey with the tourist producer, value is created, but it was unclear if he was satisfied or not.

The descriptive analysis shows that tourists don't opt anymore for traditional deals, they prefer to live personalized travel experiences based on their own needs and expectations as they know that unique tourist experiences can only be achieved through their active participation in the creation of the service. To do this, they are willing to invest and collaborate with tourism producers. The main finding of our study is that (Moroccan) tourists think they can co-create value with the tourism businesses via Internet, the idea of involvement and collaboration will generate their satisfaction. Indeed, to be independent and responsible for his choices, to be involved in the process in order to define a customized travel experience and to have control over his trip, create ultimately a sense of excitement for the tourist who is already satisfied with the experience he will live.

Otherwise, difficulties which we encountered during the survey were about explaining the new concept to tourists. In fact, they faced a new approach to design their trip, which required more time and patience especially. Respondents clearly expressed their will to discover the concept and their strong interest in participating in this process, which proves to be auspicious for tourism professionals who have not incorporated this practice into their strategy yet.

The limitations of this study are that most of the tourists don't know the concept and have never had an opportunity to do it. Thus, tourists responded following their perception and thoughts. Another limitation is related to the fact that this study is only descriptive while quantitative studies would be interesting to quantify data, to measure for instance the correlation between the involvement of tourists and creation of value and between their involvement and their satisfaction degree and to measure the impact of involvement degree on the satisfaction level. However, it should be noted that empirical research on this subject remains unfortunately very few (Dekhili and Hallem, 2016; Grissemann and Stokburger-Sauer, 2012). Besides, tourists interviewed did not answer all the questions which were due to misunderstanding of the concept, their different perception of involvement and value. These limitations should be considered for future research and analysis.

In the end, the co-creation in the tourism sector remains a recent research field that requires a particular focus to develop the concept so that it can benefit to the scientific community but also to tourism professionals. Future research should focus on exploring the antecedents which cause co-creation with tourists and reasons to get them involved in the process, how tourist producers can use effectively the Internet to co-create with tourists during the three phases of the tourist experience. Research should focus this time to study tourists' satisfaction after living an experience they really co-created and measure its impact. Moreover, the development of social networks like Facebook, Twitter, Instagram, the evolution of smartphones, technology, and mobile Internet have opened new interesting search paths.

\section{References:}

- Andersson, T.D. (2007). The tourist in the experience economy. Scandinavian Journal of Hospitality and Tourism, 7(1), 4658. Crossref

- Binkhorst, E. (2006). The co-creation tourism experience. Paper presented at the XV International Tourism and Leisure Symposium, Barcelona.

- Binkhorst, E., \& Den Dekker, T. (2009). Agenda for co-creation tourism experience research. Journal of Hospitality Marketing and Management, 18(2-3), 311-327. Crossref

- Boswijk, A., Thijssen, T., \& Peelen, E. (2007). The experience economy: A new perspective. Amsterdam: Pearson Education.

- Bouchet, P. (2004). L'expérience au cœur de l'analyse des relations magasin-magasineur. Recherche et applications en Marketing, 19(2), 53-71. $\underline{\text { Crossref }}$

- Buhalis, D., \& Licata, M.C. (2002). The future eTourism intermediaries. Tourism Management, 23, 207-220. Crossref

- Campos, A. C., Mendes, J., Valle, P. O. D., \& Scott, N. (2015). Cocreation of tourist experiences: a literature review. Current Issues in Tourism, 1-32. $\underline{\text { Crossref }}$

- Carù, A., \& Cova, B. (2002). Retour sur le concept d'expérience : pour une vue plus modeste et plus complète du concept. Actes des 7ème Journées de Recherche en Marketing de Bourgogne, Dijon.

- Cova, B., Dalli, D., \& Zwick, D. (2011). Critical perspectives on consumers' role as 'producers': Broadening the debate on value cocreation in marketing processes. Marketing Theory, 11(3), 231241. Crossref

- Dekhili, S., \& Hallem, Y. (2016). Un touriste co-créateur est-il un touriste heureux ? Étude de l'impact de la co-création sur le bien-être du consommateur. Management \& Avenir, (3), 15-34. Crossref

- Grissemann, U. S., \& Stokburger-Sauer, N. E. (2012). Customer Cocreation of Travel Services: The Role of Company Support and Customer Satisfaction with the Co-creation Performance. Tourism Management, 33(6), 1483-1492. Crossref

- Gross, M. J., \& Brown, G. (2006). Tourism experiences in lifestyle destination setting: The roles of involvement and place attachment. Journal of Business Research. Crossref

- Guo, L., Arnould, E.-J., Gruen, T.-W., \& Tang, C. (2013). Socializing to co-produce: Pathways to consumers' financial well-being. Journal of Service Research, 16(4), p. 549-563. Crossref

- von Hippel, E. (2005). Democratizing Innovation. Cambridge, Mass: The MIT Press.

- Holbrook, M.B. (1999). Consumer Value - A framework for analysis and research. London and New York: Routledge. Crossref

- Huang, J., \& Hsu, C. H. (2010). The impact of customer-to-customer interaction on cruise experience and vacation satisfaction. Journal of Travel Research, 49(1) 79-92. Crossref

- Ihamäki, P. (2012). Geocachers: The creative tourism experience. Journal of Hospitality and Tourism Technology, 3(3), 152175. Crossref

- Jager, K. (2009). The new tourist and co-creation as a key element of tourism destinations' competitiveness, Budapest, Budapest Business School.

- Kim, J.H. (2010). Determining the factors affecting the memorable nature of travel experiences. Journal of Travel \& Tourism Marketing, 27(8), 780-796. Crossref 
- Kreziak, D., \& Frochot, I. (2011). Co-construction de l'expérience touristique: les stratégies des touristes en stations de sport d'hiver. Décisions Marketing, 64, 23-33.

- Larsen, S. (2007). Aspects of a Psychology of the Tourist Experience. Scandinavian Journal of Hospitality and Tourism, 7(1), 718. Crossref

- Lashley, C. (2008). Marketing hospitality and tourism experiences, In H. Oh and A. Pizam (Eds.), Handbook of Hospitality Marketing Management, Oxford, UK: Butterwood-Heinemann. Crossref

- Lee, G. (2012). Modeling Consumer's Co-creation in Tourism Innovation (Doctoral dissertation). Retrieved from ProQuest Dissertations and Theses. (Accession Order No. 3510314).

- Li X., \& Petrick J.F. (2008). Tourism marketing in an era of paradigm shift. Journal of Travel Research, 46(3), 235-244. Crossref

- Lichrou, M., O’Malley, L., \& Patterson, M. (2008). Place-product or Place Narrative(s)? Perspectives in the Marketing of Tourism Destinations. Journal of Strategic Marketing. 16(1), 27-39. Crossref

- Oh, H., Fiore, A.M., \& Jeong, M. (2007). Measuring experience economy concepts: tourism applications. Journal of Travel Research, 46, 119-131. Crossref

- Payne, A., Storbacka, K., \& Frow, P. (2008). Managing the cocreation of value. Academy of Marketing Science, 36(1): 8396. $\underline{\text { Crossref }}$

- Pine, B.J., \& Gilmore, J.H. (1999). The Experience Economy: Work Is Theater and Every Business a Stage, Boston: Harvard Business School Press.

- Prahalad, C.K., \& Ramaswamy, V. (2000). Co-Opting Customer Competence. Harvard Business Review, 78(1):79-87.

- Prahalad, C. K. \& Ramaswamy, V. (2003). The New Frontier of Experience Innovation. MIT Sloan Management Review, 44(4), 12 18.

- Prahalad, C.K., \& Ramaswamy V. (2004). Co-creation experiences: the next practice in value creation. Journal of Interactive Marketing, 18(3), 5-14. Crossref

- Prebensen, N. K., Vittersø, J., \& Dahl, T. I. (2013a). Value cocreation significance of tourist resources. Annals of Tourism Research, 42, 240-261 Crossref

- Prebensen, N.K., Woo, E., Chen, J., \& Uysal, M. (2013b). Motivation and Involvement as Antecedents of the Perceived Value of the
Destination Experience. Journal of Travel Research, 52(2), 253264. Crossref

- Prebensen, N.K., Chen, J.S., \& Uysal, M. (2014). Creating Experience Value in Tourism, CABI. $\underline{\text { Crossref }}$

- Rihova, I., Buhalis, D., Moital, M., \& Gouthro, M. B. (2014). Conceptualising customer-to-customer value co-creation in tourism. International Journal of Tourism Research, 17(4), 356-363. Crossref

- Ritchie, J.R.B., \& Crouch, G.I. (2003). The Competitive Destination: A Sustainable Tourism Perspective, Wallingford, UK: CABI Publishing Crossref

- Scherer, E. (2012). Transferts de pouvoir. Cahier No. 3, Collection « Cahier de Tendances Médias de France Télévision », France Télévisions, Paris.

- Shaw, G., Bailey, A., \& Williams, A. (2011). Aspects of ServiceDominant Logic and its Implications for Tourism Management: Examples from the Hotel Industry. Tourism Management, 32(2): 207214. Crossref

- Tan, S.K., Kung, S.F., \& Luh, D.B. (2013). A model of 'creative experience' in creative tourism. Annals of Tourism Research, 41, 153-174. Crossref

- Tan, S.-K., Luh, D.-B., \& Kung S.F. (2014). A taxonomy of creative tourists in creative Tourism. Tourism Management, 42, 248259. Crossref

- Vargo, S.L., \& Lusch, R.F. (2004). Evolving to a new dominant logic for marketing. Journal of Marketing, 68(1), 1-17. Crossref

- Vargo, S. L., \& Lusch, R. F. (2006). Service-dominant logic: What it is, what it is not, what it might be, In R. F. Lusch, \& S. L. Vargo (Eds.), The service-dominant logic of marketing: Dialog, debate, and directions (pp. 43-56). Armonk, NY: ME Sharpe.

- Walls, A.R., Okumus, F., Wang, Y., \& Kwun, D.J. (2011). An Epistemological view of consumer experiences. International Journal of Hospitality and Management, 30(1), 10-21. Crossref

- Watson, R., Kitchingman, A., Gelchu, A., \& Pauly D. (2004). Mapping global fisheries: sharpening our focus. Fish Fish, 5, 168177. Crossref

- Zátori, A. (2013), Tourism experience creation from a business perspective (Doctoral dissertation). Retrieved from http://phd.lib.unicorvinus.hu/801/7/Zatori_Anita_den.pdf 